University of Michigan Law School

University of Michigan Law School Scholarship Repository

\title{
Patents and Regulatory Exclusivity
}

\section{Rebecca S. Eisenberg}

University of Michigan Law School, rse@umich.edu

Available at: https://repository.law.umich.edu/book_chapters/126

Follow this and additional works at: https://repository.law.umich.edu/book_chapters

Part of the Intellectual Property Law Commons, and the Legislation Commons

\section{Publication Information \& Recommended Citation}

Eisenberg, Rebecca S. "Patents and Regulatory Exclusivity." In Oxford Handbook on the Economics of the Biopharmaceutical Industry, edited by P. Danzon and S. Nicholson, 167-98. Oxford: Oxford University

Press, 2012.

This Book Chapter is brought to you for free and open access by the Faculty Scholarship at University of Michigan Law School Scholarship Repository. It has been accepted for inclusion in Book Chapters by an authorized administrator of University of Michigan Law School Scholarship Repository. For more information, please contact mlaw.repository@umich.edu. 


\title{
Patents and Regulatory Exclusivity
}

\author{
Rebecca S. Eisenberg \\ The Oxford Handbook of the Economics of the Biopharmaceutical Industry \\ Edited by Patricia M. Danzon and Sean Nicholson \\ Print Publication Date: Apr 2012 \\ Subject: Economics and Finance, Health, Education, and Welfare, Public Economics and Policy \\ Online Publication Date: Sep 2012 DOI: 10.1093/oxfordhb/9780199742998.013.0007
}

\section{Abstract and Keywords}

This article reexamines the sources of exclusivity for drugs, considers their limitations, and evaluates exclusivity under the new biologics legislation in light of these limitations. The current overlapping legal protections for exclusivity in the pharmaceutical marketplace reflect a series of political compromises, repeatedly renegotiated to correct for unintended consequences in the previous version of the rules. Patents and patent challenges play a central role in this system of protection, and many of the patents at stake are ultimately held invalid in litigation. It is not easy to untangle a complex legal regime that allocates billions of dollars of profits. But it makes little sense for lawmakers and trade negotiators to extend this Byzantine system into new legal regimes, either by duplicating the Hatch-Waxman Act for biosimilars or by binding US trading partners to adopt similar systems in their national laws. A simpler and more effective legal regime would rely less on patent protection and more on well-designed regulatory exclusivity to support incentives for new drug development.

Keywords: drug exclusivity, patents, patent challenges, Hatch-Waxman Act, drug policy, biosimilars, regulation

Pharmaceutical research and development (R\&D) involves both the creation of new products and the production of information about their effects through preclinical research and clinical trials. Firms might underinvest in this costly, risky, and timeconsuming $R \& D$ in the absence of subsidies, rewards, or protection from competition. This chapter examines and critiques the patent and regulatory regimes that offer drug developers temporary shelter from competition. The principal focus is on US law, with some attention to different rules that prevail in the European Union (EU).

The patent system works in tandem with drug regulation to defer market entry by competitors, thereby preserving profitable exclusivity in the market for a new drug more effectively than patents could do without the regulatory assist (Eisenberg 2007). Under 
the Federal Food, Drug, \& Cosmetic Act (FDCA), ${ }^{1}$ the US Food and Drug Administration (FDA) requires the submission of data showing safety and efficacy before it approves new drugs for sale. This entry barrier both adds to the costs of drug development and protects drug developers from competition. At least since passage of the Orphan Drug Act of $1983^{2}$ and the Drug Price Competition and Patent Term Restoration Act of 1984 (commonly known as the Hatch-Waxman Act), ${ }^{3}$ Congress has deliberately deployed regulatory entry (p. 168) barriers to shelter research performers from competition. The Hatch-Waxman Act charged the FDA with administering periods of regulatory exclusivity before it allows generic competitors to use a less costly Abbreviated New Drug Application (ANDA). These periods turn in part on the terms of any relevant patents, and patent terms turn in part on extensions to compensate for regulatory lags in product approval. Patents and drug regulation are pervasively intertwined in the Hatch-Waxman scheme, creating considerable complexity and uncertainty.

The regulatory regime governing most biotechnology products until quite recently has been different. The FDA generally regulates these products as "biologics" under the Public Health Service Act (PHSA) ${ }^{4}$ rather than as drugs under the FDCA. ${ }^{5}$ The biotechnology industry was in its infancy when the Hatch-Waxman Act was passed in 1984, and that Act did not create a corresponding abbreviated approval pathway for biologics under the PHSA. Generics manufacturers had only limited success in using the Hatch-Waxman provisions to gain approval for generic versions of biologic products (Dinh 2007). Twenty-six years after the Hatch-Waxman Act, the U.S. Congress enacted an abbreviated approval process for products that are "biosimilar" to previously approved biologic products, on somewhat different terms than those available for generic drugs under the Hatch-Waxman Act. 6

This chapter reexamines the sources of exclusivity for drugs, considers their limitations, and evaluates exclusivity under the new biologics legislation in light of these limitations.

\section{Patent Protection for Pharmaceutical Products and Methods}

Although biopharmaceutical innovation is often counted as a success story for the patent system (Bessen and Meurer 2008), many of the patents that drug companies rely on for exclusivity ultimately prove vulnerable to validity challenges brought by generic competitors. Such challenges have become increasingly common and (p. 169) arise ever earlier in the commercial life of pharmaceutical products as firms have responded to incentives in the Hatch-Waxman Act (Grabowski and Kyle 2007), triggering judicial scrutiny that many patents have been unable to withstand. The vulnerability of so many pharmaceutical patents to validity challenges calls into question how well patent doctrine works in this particular context (Roin 2009). 


\section{The Asynchrony of Patents and Drug Development}

Under U.S. law, ${ }^{7}$ in order to be patentable an invention must be new, ${ }^{8}$ useful, ${ }^{9}$ and nonobvious. ${ }^{10}$ The inventor must file a patent application that provides a written description of the invention and enables a person skilled in the field to make and use it. ${ }^{11}$ Failure to satisfy these requirements may lead to rejection of a patent application ${ }^{12}$ or to later invalidation of an issued patent. ${ }^{13}$

The patent claims that are most effective at securing exclusivity are those that cover the drug molecule as a new composition of matter. But the invention of new molecules occurs at an early stage in the course of drug development, before therapeutic value is validated in clinical trials. Patent law promotes early filing on these inventions to minimize the risk that publication or public use will make them ineligible for patenting, but at that stage much work remains to be done before the molecules may be approved for commercial sale. The FDA estimates that it takes on average 81/2 years to study and test a new drug before the FDA can approve it for sale to the public (FDA 2006); industry estimates are even higher, ranging from 10 to 15 years (Pharmaceutical Research \& Manufacturers of America [PhRMA] 2007). This time lag can pose challenges for patent seekers. In the early stages of (p. 170) drug development, researchers may not know enough about new molecules to meet requirements for patent protection. Moreover, patents with early filing dates have early expiration dates. Later-filed patents, on the other hand, are more constrained by prior art and thus more likely to be either invalid or too narrow to provide meaningful exclusionary rights.

\section{Patenting in the Early Stages of $R \& D$}

There are many reasons for innovating firms to seek patent protection as early as possible. The issuance of a patent promises future protection against competitors, making it easier to profit from developing inventions into commercial products. Without this promise, firms are usually unwilling to incur the costs of clinical trials. Firms evaluate drug candidates for patentability early and drop candidates that they cannot patent. New firms may be unable to attract investment capital to pursue clinical trials without patent protection (Roin 2009).

Patent law promotes early filing on new inventions because patentability depends on how an invention compares to the "prior art," including publications, patents, and public knowledge or use. ${ }^{14}$ If the prior art discloses an invention or makes it obvious, it may not be patented. The later a patent application is filed, the more extensive the prior art. An inventor's own publications, published patent applications, or public use constitute prior art that may prevent later patenting of the disclosed work or of obvious variations. ${ }^{15}$ It may become necessary to claim an invention narrowly in order to distinguish it from the prior art. For example, if the prior art discloses one form of the active ingredient in a drug, that disclosure will make it impossible to obtain a broad patent claim that would cover many variations on that active ingredient (such as different salt forms or hydrates). A narrower claim limited to a newly identified variation, use, or formulation might still be 
allowable if it is not obvious in light of the prior art. But these narrower patents, even if valid, may be easier for competitors to avoid infringing. Earlier filed patent applications, because they face less prior art, qualify for broader claims and therefore offer more effective protection against competition.

Despite the commercial and doctrinal advantages of early filing, the time lag between the discovery of a new molecule and the development of information necessary to use that molecule as a drug may make early filing difficult.

First, without some research into the properties of a molecule, it may be difficult to satisfy the "utility" and "enabling disclosure" requirements. The patent (p. 171) statute limits protection to inventions that are "useful,"16 and requires patent applicants to disclose their inventions "in such full, clear, concise, and exact terms as to enable any person skilled in the art ... to make and use the same." 17 The US Supreme Court has held that it is not enough to show that as of the filing date the invention is an object of "usetesting." 18 Subsequent lower court decisions have generally found promising in vitro test results adequate to demonstrate patentable utility, ${ }^{19}$ but in some cases courts have required clinical testing to support controversial claims of therapeutic utility. ${ }^{20}$ Delays in patent filing to gather data to establish utility may lead to future rejection for lack of novelty if, in the interim, the molecule itself has been published or otherwise disclosed. For example, if an early patent application that discloses a new molecule is published 18 months after its filing date ${ }^{21}$ it becomes prior art even if the application is rejected for failure to meet the utility requirement (Roin 2009). Once the molecule is in the prior art, an inventor who later finds a use for it may no longer patent the molecule itself, although it may be possible to get a narrower patent on a method of use. But a patent that claims only a method of use is of limited value because it will not prevent others from making, using, or selling the same molecule for other uses.

Second, if a new drug is structurally similar to a prior art molecule, further research may be necessary to satisfy the nonobviousness requirement. The courts and the Patent and Trademark Office (PTO) have developed a distinct approach for evaluating the nonobviousness of chemicals created by making small changes in prior art molecules. ${ }^{22}$ Under this approach the existence of a structurally similar molecule in the prior art makes the new variation prima facie obvious. The patent applicant may rebut prima facie obviousness with evidence of surprising properties (or particularly advantageous properties) not present in the prior art. ${ }^{23}$ To make this showing, it may be necessary to perform tests on both the new chemical and the prior art chemical. If the obviousness challenge does not arise until after the product has been thoroughly tested, the patent holder may use studies performed after the patent filing to show surprising or advantageous properties. ${ }^{24}$ But if the (p. 172) PTO rejects the application at the outset for prima facie obviousness, the need to develop rebuttal evidence may cause delays. Meanwhile, firms might hesitate to invest in costly testing without the promise of patentability. 


\section{Patents and Regulatory Exclusivity}

The "surprising properties" narrative aligns poorly with the nature and timing of risktaking in drug development. Some surprising properties of new chemicals are immediately apparent upon synthesis. But the most important properties of drugs-safety and efficacy for therapeutic purposes-require validation through testing and observation over time. Drug development involves focused searches for desirable properties more often than serendipitous surprises. Firms typically select for further testing those molecules that they most expect to succeed, although most molecules ultimately disappoint early expectations. In the face of high hopes, surprising properties are more likely to be bad news than good news; in that case patentability may be a dubious consolation prize rather than a valuable incentive. A rule that promises patent protection only after testing reveals surprising properties may thus fail to motivate investments in clinical trials of promising candidates to confirm hoped-for properties.

When patentability is delayed by the need to do studies to prove utility or to show surprising properties, investments in drug development become more risky. Intervening prior art may force patent applicants to abandon or, more likely, to narrow their claims, making it easier for competitors to enter the market in the future if the product is successful. If commercially effective patent protection seems fraught with uncertainty, a firm may drop a product from further development.

The effects of uncertain patent rights may be mitigated somewhat by the increasing presence in early-stage biopharmaceutical R\&D of biotechnology firms that have a higher tolerance for risk than traditional pharmaceutical firms. These firms may be willing to continue pursuing early-stage research projects that risk-averse pharmaceutical firms would abandon (Lou and deRond 2006), making it less likely that valuable products will die on the vine. Later, after further research reduces the risk that these products will fail, pharmaceutical firms might be willing to in-license the products to shepherd them through clinical trials and market launch (Mayhew 2010). Weakness in the patent position supporting these products will diminish their value to licensees or other investors, but perhaps further research will have yielded additional patents.

\section{Limitations on Patents Available in Later Stages of R\&D}

Successful drugs are typically covered by multiple patents, with new applications filed throughout the product life cycle (Furrow 2008). Firms have tried different patent strategies to prolong exclusivity in a successful drug, including patenting drug metabolites, patenting a single enantiomer isolated from a racemic mixture (Agranat and Wainschtein 2010), and patenting new dosage forms or combination products. Many of these patents have been challenged by generic competitors, often successfully. The most significant obstacles to patenting follow-on inventions are novelty and nonobviousness.

(p. 173) Follow-on patents violate the novelty standard if they cover products and methods that are in the prior art, either explicitly or inherently. This rule makes broad patent claims in follow-on patents invalid. For example, in Schering $v$ Geneva ${ }^{25}$ the patent at issue claimed descarboethoxyloratadine (DCL), a metabolite of loratadine. The prior art included an expired patent on loratadine. Schering sought to enforce the DCL 
patent against the sale of generic loratadine by arguing that patients who ingested loratadine would necessarily produce DCL in their guts, thereby infringing the DCL patent. The court held the DCL patent invalid, reasoning that if, as both parties agreed, administering loratadine to patients inherently causes the production of DCL, DCL became prior art when the earlier loratadine patent disclosed administering loratadine to patients. A narrower claim to the metabolite in isolated form might have survived this challenge, but such a claim would not preclude competitors from selling loratadine.

Patents claiming modest changes that are sufficient to avoid a novelty challenge have often been held invalid for obviousness, including claims to new dosages, ${ }^{26}$ new formulations, ${ }^{27}$ combination products that package the drug with another familiar ingredient in a single capsule, ${ }^{28}$ and single enantiomers or diastereomers isolated from a racemate or other mixture of stereoisomers. ${ }^{29}$ To avoid invalidation for obviousness, the patent holder must show either that a person working in the field would not have found the modification obvious or that the modified version has surprising properties not present in the prior art. This has proved to be a significant obstacle for many follow-on patents (Eisenberg 2008).

\section{Patent Duration and Term Extension}

The term of a patent aligns poorly with the economic life cycle of a drug. Although firms file for patents in the early stages of drug development, patents confer little competitive advantage before a product is on the market. Most uses of drugs during the premarket stage fall within the Hatch-Waxman exemption from infringement for the use of a patented drug "solely for uses reasonably related to the submission of information under a Federal law which regulates the manufacture, use or sale (p. 174) of drugs. ..."30 The US Supreme Court has interpreted this exemption to cover not only clinical trials and bioequivalence studies but also preclinical laboratory research. ${ }^{31}$ This leaves little room for enforcement of patents against competitors in the premarket stage.

By the time a drug gets to market, some early-filed patents may have little remaining life. Today, most patents expire 20 years after their filing date. ${ }^{32}$ This term has long been standard throughout the world, but the United States did not adopt a 20-year patent term until 1994, ${ }^{33}$ when it amended its patent laws to comply with the multilateral Agreement on Trade-Related Aspects of Intellectual Property Rights, known as the TRIPS Agreement. ${ }^{34}$ Before that time, US patents expired 17 years after the date of issuance, and patents issued on US applications filed before June 8, 1995 still get the benefit of this expiration date if it is later than 20 years after the filing date. ${ }^{35}$ The 17 -year term is advantageous for patent applications that are pending for longer than three years; the longer the pendency, the greater the advantage.

Patent applicants who filed before the 1995 transition date can potentially gain commercial advantage by using continuations ${ }^{36}$ and prosecution delays to keep their applications pending for years, relying on early filing dates to limit exposure to prior art while deferring their patent terms until they need protection from competition. Although the number of patents that can take advantage of this transitional provision is 
diminishing, some patent applicants continue to use it. ${ }^{37}$ An important limitation on this strategy is the judicial doctrine of "double-patenting," which prevents an applicant from obtaining multiple successive patent terms on (p. 175) the same invention or on obvious variations thereon. ${ }^{38}$ If the second patent is not "patentably distinct" from the first, it requires a "terminal disclaimer" that causes it to expire at the same time as the first patent. ${ }^{39}$ This complex doctrine should diminish in importance with the gradual disappearance of patent filings eligible for the 17-year term, but because of the substantial values at stake it continues to be the focus of considerable litigation in the pharmaceutical industry. ${ }^{40}$

A patent on an FDA-approved drug may be entitled to a term extension of up to five years to compensate for some of the time lost during clinical trials and regulatory review. ${ }^{41}$ The remaining patent life after extension may not exceed 14 years beyond the date of FDA approval. ${ }^{42}$ The period of extension includes one-half of the time spent in clinical trials and all of the time between submission and approval of the NDA. ${ }^{43}$ Both periods are reduced by any time attributable to an applicant's lack of diligence. ${ }^{44}$ Only the first approval of a new active ingredient qualifies for a patent term extension, and only one patent may be extended per new active ingredient. ${ }^{45}$ The patent to be extended must be in force on the date of approval ${ }^{46}$ and must cover either the product, a method of using the product, or a method of manufacturing the product. ${ }^{47}$

These provisions present a firm with a strategic dilemma: should it extend an early-filed patent that expires sooner but is more likely to survive a validity challenge, or a follow-on patent that potentially confers more years of exclusivity but is narrower and more vulnerable to patent-defeating prior art? Sometimes follow-on patents are all that remain. ${ }^{48}$ With generic firms racing to challenge vulnerable patents, the risks and stakes are high.

\section{(p. 176) Patents and the Timing of Generic Approval}

The Hatch-Waxman Act fundamentally altered drug patent enforcement in the United States. Before Hatch-Waxman, generic versions of previously approved drugs faced two major entry barriers: first, the FDA approval process, which generally required the same showing of safety and efficacy for a generic product as for a pioneering drug, ${ }^{49}$ and second, patents, which private owners could enforce through infringement actions in the courts. ${ }^{50}$ The FDA entry barrier was usually sufficient to defer generic entry long after relevant patents had expired, because the costs of clinical trials were prohibitive for generic products that would be sold at competitive prices (Mossinghoff 1999). The HatchWaxman Act lowered the regulatory entry barrier considerably by allowing approval of a generic product that is "bioequivalent" to a previously approved product under an ANDA, without requiring duplication of safety and efficacy trials. ${ }^{51}$ At the same time, it fortified the patent entry barrier by creating a system within the FDA for tracking drug patents and deferring the availability of ANDAs during the patent term. The Hatch-Waxman Act set up a complex process, fraught with unintended consequences, to divert disputed 
patent issues to the courts and to motivate potential competitors to challenge the validity of patents. Patent challenges have become increasingly common and are frequently successful, exposing weaknesses in the patent system for drugs.

\section{Patents at the FDA}

The FDCA requires that an NDA disclose any patent that claims the drug or a method of using the drug "with respect to which a claim of patent infringement could reasonably be asserted if a person not licensed by the owner engaged in the manufacture, use, or sale of the drug." 52 On approval of the NDA, the FDA (p. 177) publishes this information, updated to include later patents, in a publication called "the Orange Book," which is available on the FDA website. ${ }^{53}$ This information determines the timing of FDA approval of ANDAs under an intricate set of rules.

The statute requires that an ANDA include one of four prescribed "certifications" with respect to each patent in the Orange Book for the previously approved "listed drug"54: a "paragraph I certification" indicating that no patent information has been filed; a "paragraph II certification" indicating that the patent has expired; a "paragraph III certification" indicating the date on which the patent will expire; or a "paragraph IV certification" indicating "that such patent is invalid or will not be infringed by the manufacture, use, or sale of the new drug for which the application is submitted." 55 If there are no relevant patents still in force, the ANDA may be approved without further delay, ${ }^{56}$ assuming it is otherwise approvable. ${ }^{57}$ If a patent is still in force, the ANDA may be approved upon its expiration date. ${ }^{58}$ The consequences of a paragraph IV certification are complex.

An applicant making a paragraph IV certification must give notice within 20 days to each owner of the patent and to the holder of the approved NDA including "a detailed statement of the factual and legal basis of the opinion of the applicant that the patent is invalid or will not be infringed." 59 The ANDA may then be approved immediately, unless an action for patent infringement is brought within 45 days. The filing of a patent infringement action triggers a 30-month stay of approval of the ANDA, subject to adjustment by the court. ${ }^{60}$ The first firm to file an ANDA with a paragraph IV certification for a listed drug gets a 180-day head start before the FDA will approve another ANDA with a paragraph IV certification for the same product. ${ }^{61}$ These provisions have been litigated extensively as firms have explored their strategic implications.

One effect of the Hatch-Waxman Act has been to shift some of the burden of patent enforcement from patent owners to the FDA by directing the FDA to refrain from approving ANDAs during the patent term. In the absence of a paragraph IV certification, the FDA will use its gatekeeper role to exclude competitors until (p. 178) the patents listed in the Orange Book expire, without the need for infringement litigation. Patent holders need not monitor competitors to detect infringement; the burden is on firms seeking to enter the market to address infringement of listed patents when they file ANDAs. Even when an ANDA filer challenges the patent in a paragraph IV certification, a patent holder who brings an infringement action gets an automatic 30-month stay of 
approval of the ANDA, without having to meet judicial standards for a preliminary injunction. ${ }^{62}$ These features of the statute fortify the exclusionary effect of patents outside the courts through the use of heightened regulatory entry barriers during the patent term.

To be sure, these provisions only defer the use of ANDAs; they do not prevent a competitor willing to conduct its own clinical trials from submitting a full NDA, nor do they prevent the FDA from approving such an NDA, even during the patent term. So long as NDA requirements are cost-prohibitive for generics, however, the FDA-administered remedy of deferring the use of ANDAs is at least as effective in deferring competition as judicial remedies for patent infringement.

A distinct advantage for patent holders of the FDA-administered remedies is that, unlike a court, the FDA makes no effort to determine whether patents listed in the Orange Book are valid and infringed, or even whether they claim the listed drug or its use. FDA relies on the NDA sponsor to identify which patents are appropriate for listing in the Orange Book, and if anyone disputes the accuracy of the patent information or the propriety of listing a particular patent, the FDA relies on the sponsor to decide whether to change the listing or to leave it as is. ${ }^{63}$ FDA does not itself consider the merits of paragraph IV certifications but simply defers approval of ANDAs for 30 months pending further instructions from the courts. All listed patents get the same administrative treatment regardless of their validity or scope.

For a while, 30-month stays appeared to be a potentially never-ending source of exclusivity for NDA holders, so long as they could continually refresh their stock of patents in the Orange Book and obtain additional 30-month stays for each new patent (Federal Trade Commission [FTC] 2002). After the FTC documented this emerging practice in a 2002 report, the FDA implemented a rule that (p. 179) had the practical effect of limiting NDA holders to one 30-month stay per ANDA, regardless of the number of listed patents and paragraph IV certifications (FDA 2003b). Congress promptly endorsed this administrative policy with a somewhat different limitation as part of the Medicare Prescription Drug, Improvement and Modernization Act of 2003, ${ }^{64}$ excluding stays for patents added to the Orange Book after the ANDA filing date. ${ }^{65}$ Either way, the effect is to limit the duration of the stay to a single period of 30 months.

The new statutory limitation makes it advantageous to file ANDAs with paragraph IV certifications as soon as possible ${ }^{66}$ to run out the clock on the 30 -month stay. The HatchWaxman Act also encourages prompt filing of paragraph IV certifications by rewarding the first firm to file an ANDA with a paragraph IV certification for a listed drug with a 180-day period of "generic exclusivity" before FDA may approve another ANDA with a paragraph IV certification for the same product. ${ }^{67}$ The result has been a race to file ANDAs with paragraph IV certifications ${ }^{68}$ and an explosion of patent infringement litigation at the ANDA stage.

\section{ANDA Infringement Litigation}


ANDA infringement litigation allows the courts to resolve disputes about patent validity and infringement prior to generic entry. It differs from ordinary infringement litigation in ways that give the generic challenger greater control. Although the patent holder is formally the plaintiff, it is the generic challenger that decides whether to provoke the lawsuit by filing a paragraph IV certification. If the patent holder fails to file an infringement action within 45 days, it forfeits the 30-month stay of approval of the ANDA, risking immediate loss of market share to generic competition. Moreover, the generic challenger may bring a declaratory judgment action to establish that the patent is invalid or will not be infringed by the generic product. ${ }^{69}$ The generic challenger can also set the terms of the litigation, both by selecting the patents to challenge and by defining the accused product and method of treatment for which it seeks approval in its ANDA.

(p. 180) The Hatch-Waxman Act altered the statutory definition of patent infringement to allow both bioequivalence studies of generic drugs and adjudication of patent disputes to occur before generic entry. ${ }^{70}$ Under the new definition, the filing of an ANDA "for a drug claimed in a patent or the use of which is claimed in a patent" is itself an act of infringement, subjecting the ANDA filer to injunctive relief (but not damages) prior to the sale of a commercial product. ${ }^{71}$ The focus of ANDA infringement analysis is the proposed product and use for which the applicant seeks approval, rather than an actual commercial product or use. The generic challenger may thus avoid liability by drafting the ANDA to specify a composition that falls outside the scope of the patent claims ${ }^{72}$ or by limiting the uses for which it seeks approval to avoid method of use claims. ${ }^{73}$ If the generic product becomes commercially available during the patent term, ${ }^{74}$ the patent holder may bring another infringement action for damages and injunction against the actual commercial product, even if the hypothetical product for which the same firm sought approval in the ANDA was held not to infringe in the course of the ANDA infringement action. ${ }^{75}$ Litigating patent disputes prior to generic entry benefits holders of valid patents by forestalling competition, but it also minimizes risks for generic challengers by allowing them to challenge patents before they expose themselves to liability for money damages by launching an infringing commercial product. ${ }^{76}$ (p. 181) Deferral of FDA approval is the most significant remedy at stake in ANDA litigation. ${ }^{77}$

Typically the patent holder has much more at stake in ANDA litigation than the generic challenger. If the patent holder prevails, the court will likely direct the FDA to defer approval of the ANDA until the end of the patent term. Assuming no other ANDA filer successfully challenges the patent, ${ }^{78}$ the patent holder could remain the sole source of the drug for the remaining patent life, an outcome that could be worth billions of dollars in the case of a blockbuster product. If the generic challenger prevails, its ANDA will be approved, and if it was the first ANDA with a paragraph IV certification for that product, it may be the only ANDA-approved generic on the market for 180 days. Because the first generic competitor in the market for a drug typically charges higher prices and captures a larger market share until a second generic competitor enters the market, this period of generic exclusivity has significant value (Congressional Budget Office 1998). The value of generic exclusivity is diminished if multiple ANDA filers share the exclusivity ${ }^{79}$ or if the NDA holder decides to launch its own competing "authorized generic" during the generic 


\section{Patents and Regulatory Exclusivity}

exclusivity period (Thomas 2006). ${ }^{80}$ A 2009 FTC report on authorized generics stated that, on average, expenditures at wholesale prices of a generic during the 180-day exclusivity period equal 61 percent of expenditures on the brand name product during a comparable period before generic entry (FTC 2009a). Once the generic exclusivity period expires (p. 182) and more generic competitors enter, price competition is likely to reduce profits considerably. Even with generic exclusivity, the profits that a generic challenger hopes to gain in the patent challenge are likely to be a fraction of the profits the patent holder hopes to preserve.

Given uncertainty as to the outcome and litigation costs, this gap between the value and risks to the patent holder and to the generic challenger makes it tempting to try to reach a settlement. Some settlement agreements have provoked antitrust scrutiny by providing for "reverse payments" from the patent holder to the generic challenger in exchange for agreement by the challenger to defer market entry (Hemphill 2009; FTC 2010). Before the 2003 statutory amendments, these agreements could potentially preclude all generic entry so long as any patents remained in the Orange Book for the listed drug. This is because, under previous statutory provisions, the FDA could not approve subsequent ANDAs with paragraph IV certifications until 180 days after either (1) the first commercial marketing of the product by the first ANDA filer or (2) a court decision holding the challenged patents invalid or not infringed (FTC 2002). Settlements could prevent either of these triggers from occurring, thus postponing indefinitely the time when competing ANDAs could be approved. The revised statute addressed this problem with several different patches. ${ }^{81}$

The FTC, with the support of a number of antitrust scholars, sees most settlements that involve reverse payments to defer generic entry as agreements in restraint of trade in violation of the antitrust laws (Hovenkamp et al. 2003, 2004; O’Rourke and Brodley 2003; Hovenkamp 2004; Leffler and Leffler 2004; FTC 2010). Although owners of valid patents are entitled to exclude competitors from the market until the end of the patent term, antitrust authorities may suspect that settlements with reverse payments signal weak patent claims. ${ }^{82}$ But in the ANDA litigation context, the inference of a weak patent is not as compelling as might first appear. Even a victorious patent holder could not recover damages from a defendant that is not yet selling a product, and even an optimistic patent holder would presumably give up some portion of expected profits in settlement to reduce the risk of a litigation loss. One might therefore expect settlement of even strong patent infringement claims to involve reverse payments. So far, most courts considering (p. 183) the issue have rejected the antitrust claims, ${ }^{83}$ with the support of another group of antitrust scholars (Crane 2002, 2004; Schildkraut 2004).

Congress has implemented reforms suggested by the FTC to minimize anticompetitive abuses, including revisions to the 180-day exclusivity period, ${ }^{84}$ and has ensured continuing antitrust oversight by requiring that ANDA litigation settlement agreements be filed with the FTC and the Justice Department within 10 days of execution. ${ }^{85}$ The 
prospect of antitrust enforcement presumably reduces the expected value of settlements and prolongs litigation.

This complex regime is clearly far from optimal. Current law reflects repeated compromises to rebalance the interests of innovators and generic competitors as Congress seeks to block abuses, with each legislative patch inevitably introducing a new set of unintended consequences. It is complex and provokes costly litigation with unpredictable results. An interesting side effect is that this system shines a bright judicial spotlight on the patent portfolios of the pharmaceutical industry to reveal an uncomfortable truth: many of the patents are invalid.

\section{Regulatory Exclusivity for Drugs}

Congress has repeatedly provided exclusive rights for pharmaceutical innovators outside the patent system by controlling the timing of regulatory entry barriers. These rights promote certain forms of R\&D, such as the development of orphan drugs or new chemical entities (NCEs) or the testing of approved drugs for new uses or for use in children. The terms of protection vary. Sometimes regulatory exclusivity runs concurrently with patent protection, and sometimes it extends beyond the patent term. Although shorter in duration than patents, most forms of regulatory exclusivity are better synchronized than patents at the front end with the timeline of drug development, deferring generic entry while the product (p. 184) is earning money rather than running the meter before product launch. When patent validity and infringement are contested and uncertain, regulatory exclusivity provides a minimum period of exclusivity that is less vulnerable than patent protection to challenge. Moreover, legislators enjoy greater latitude in designing regulatory exclusivity provisions to meet the needs of the pharmaceutical marketplace, unconstrained by the strictures of a one-size-fits-all patent system that applies essentially the same rules to all fields of technology.

\section{Orphan Drugs: Market Exclusivity}

The Orphan Drug Act of $1983^{86}$ is an early example of regulatory exclusivity, directing the FDA to grant seven years of market exclusivity for products to treat rare diseases and conditions affecting fewer than 200,000 patients in the United States. ${ }^{87}$ Available for both drugs and biologics, Orphan Drug exclusivity does not merely defer the use of an ANDA. It entirely prohibits approval of another application "for such drug for such disease or condition" for seven years after the initial product approval, even if the later applicant conducts its own clinical trials. It does not, however, preclude approval of either (1) another drug for the same disease or condition, or (2) the same drug for another disease or condition. ${ }^{88}$ The FDA has interpreted the statute to permit approval of a "clinically superior" product that uses the "same active moiety." 89 


\section{Patents and Regulatory Exclusivity}

Market exclusivity under the Orphan Drug Act is similar to a patent on a particular use of a drug, enforced by FDA, with the drug narrowly defined to exclude "clinically superior" formulations. Although one might expect orphan drugs to have markets too small to be lucrative, many products qualifying for Orphan Drug exclusivity have had large and profitable markets (Pulsinelli 1999). The Orphan Drug Act may provide protection for new uses of old drugs that were taken off the market and for which early patents have expired, such as thalidomide (Perri and Hsu 2003). But because Orphan Drug exclusivity does not extend to other uses for the same product, it is of little value for products that competitors are free to sell for other previously approved indications. ${ }^{90}$

\section{(p. 185) Hatch-Waxman: Data Exclusivity}

In 1984 Congress added two more provisions for regulatory exclusivity in the HatchWaxman Act, providing five years of data exclusivity for NCEs not previously approved by the FDA ${ }^{91}$ and three years of data exclusivity for changes in a previously approved product requiring new clinical trials to win supplemental NDA approval. ${ }^{92}$ In contrast to the Orphan Drug Act provisions, these Hatch-Waxman Act provisions merely prevent competitors from using an ANDA. They do not prevent a competitor willing to conduct its own clinical trials from obtaining approval of its own NDA. In this sense, they resemble FDA-administered proprietary rights in regulatory data, deferring the time when competitors may rely on the innovator's prior showing of safety and efficacy, although the practical effect is to defer generic competition. Sometimes the term "data exclusivity" refers to periods of delay before an abbreviated approval pathway may be used, whereas "market exclusivity" refers to a more robust form of exclusion such as that available under the Orphan Drug Act; however, usage is not entirely consistent.

\section{NCE Exclusivity}

The period of exclusivity for an NCE begins with first market approval and therefore often runs concurrently with patent protection, although in some cases it may last longer (Junod 2004). Although it is sometimes referred to as "five-year exclusivity," the effective period of protection is usually longer than five years. During the statutory period, one may not even submit an ANDA to the FDA; it takes an average of 19.2 months after submission of an ANDA for the FDA to approve the drug for marketing, extending the time before generic entry (FDA 2007). If the ANDA includes a paragraph IV certification, it may be submitted as early as four years after approval of the NCE, but if the patent holder brings an infringement action within the next year, the 30-month stay is extended to give a total of $7 \frac{1}{2}$ years from initial NDA approval to the time of ANDA approval. ${ }^{93}$ With these qualifications, in practice the period of exclusivity from first approval of the NCE until approval of an ANDA is likely to range from a minimum of $5 \frac{1}{2}$ years (if an ANDA with a paragraph IV certification is filed after four years, no infringement action is filed, and the FDA takes 1 1/2 years to approve the ANDA) to a maximum of $7 \frac{1}{2}$ years (if an infringement action is filed and the 30-month stay is extended in accordance with the 
statute), although approval times vary, and a court might lengthen or shorten the stay. In the absence of patents, the period of exclusivity is five years plus approval time, or approximately $6 \frac{1}{2}$ years.

Relatively few NDAs do not involve patents, but some involve invalid patents. NCE exclusivity provides four years before such a product might face a (p. 186) patent challenge and $7 \frac{1}{2}$ years before a patent challenger can enter the market under an ANDA.

\section{Supplemental NDA Exclusivity}

So-called "three-year exclusivity" arises when the FDA approves a supplement to a previously approved NDA that required further clinical trials for approval. ${ }^{94}$

Supplemental NDAs are necessary to market a drug for a new indication, or in a different dosage form or formulation, or to sell the drug over the counter (OTC) rather than by prescription only. The three-year period begins with approval of the supplemental application, making it advantageous to defer filing a supplemental NDA until other forms of exclusivity are at an end in order to prolong the total period of exclusivity. As a product approaches the end of its patent life, a firm might seek approval to switch from prescription to OTC sales, thereby gaining three years before it faces generic competition in the OTC market. The three-year period ends with ANDA approval, not with submission. The FDA may not approve an ANDA for the same change during the exclusivity period, but it may receive and review applications and grant tentative approval that becomes effective when the exclusivity expires. The additional years of exclusivity are available only if additional clinical trials were necessary to get the supplement approved. ${ }^{95}$

The exclusivity thereby gained is limited to the terms of the supplemental approval and will not prevent a competitor from using an ANDA to get approval to sell the product as previously approved. This is a significant limitation on the exclusive rights conferred by a supplemental NDA to market a drug for a new indication. ${ }^{96}$ Three-year exclusivity does not stop a generic competitor from getting approval to sell its product for the original indication. Once the generic version is on the market, physicians are free to prescribe it off-label for the new indication, and pharmacists may substitute the generic version unless physicians expressly require that the originator brand be used. Indeed, unless the new indication involves a different formulation of the product, state generic substitution laws may require substitution of the cheaper generic product at the pharmacy (Grabowski and Vernon 1979). A similar problem limits the value of both Orphan Drug exclusivity and method-of-use patents for products with multiple therapeutic uses.

Three-year exclusivity remains commercially valuable in circumstances in which generic substitution is unlikely, such as a prescription to OTC switch. If the branded product becomes available OTC and the generic product is available only by prescription, patients may switch to buying the branded product directly at the (p. 187) pharmacy rather than seeing a doctor for a prescription. Three years of exclusivity in the OTC market may give the branded product a dominant position with consumers that persists even after generic entry in the OTC market (Mahecha 2006). 
A design flaw in three-year exclusivity is that, because it begins with approval of the supplemental NDA, it is advantageous for firms to defer filing such supplements until they are about to lose other exclusivity. Otherwise, the three-year period would run concurrently with other protection without further deferring competition. The result may be to lead firms to defer incremental innovation that could have occurred earlier.

\section{Pediatric Exclusivity: Prolonging Existing Rights}

The Food and Drug Administration Modernization Act of 1997 added six months of exclusivity as a reward for conducting pediatric trials of drugs. ${ }^{97}$ This six-month period of "pediatric exclusivity" is not contingent on approval of the drug for use in children and is not limited to such use. The only requirements are that the FDA must request the pediatric studies, and they must be completed and submitted within the timeframe specified by the FDA.

In contrast to the Hatch-Waxman Act and Orphan Drug Act exclusivities, the six-month pediatric exclusivity does not start running immediately on FDA approval. It simply extends by six months the end dates of any existing forms of exclusivity held by the submitter, whether under a patent, the Orphan Drug Act, or Hatch-Waxman Act provisions, ${ }^{98}$ further deferring the time when the FDA might approve a competing generic product. It does not run concurrently with other forms of exclusivity, and there is no advantage to be gained by deferring pediatric trials. The provision is currently set to expire in 2012, ${ }^{99}$ but Congress has repeatedly extended it and may do so again, although in prior legislative debates some legislators suggested that six months of exclusivity is an excessive reward for rather modest expenditures on pediatric trials (Steinbrook 2002).

\section{(p. 188) Regulatory Exclusivities in Other Countries}

Longer periods of regulatory exclusivity are available in the EU, dating back to a time when some members of the EU did not allow patents on pharmaceuticals (Junod 2004). ${ }^{100}$ The European regime currently provides for eight years of exclusivity before authorization for a generic may be submitted and two further years before it may be approved; each of these dates is extended by an additional year if, during the first eight years, the holder of the authorization obtains further authorization for one or more new therapeutic indications for the product. ${ }^{101}$ By disentangling the duration of exclusivity from the timing of supplemental approval, the European approach encourages the testing and submission for approval of new indications earlier in the life cycle of a drug relative to the US approach.

The pharmaceutical industry has sought to establish regulatory exclusivity regimes throughout the world in the terms of trade agreements, with mixed success (Reichman 2009; Fellmeth 2004). The multilateral TRIPS Agreement, in lieu of a proposed requirement for a minimum of five years of regulatory exclusivity, ambiguously requires 
members of the World Trade Organization to protect undisclosed data against "unfair commercial use" and against "disclosure, except where necessary to protect the public." 102 Subsequent regional and bilateral free trade agreements more clearly specify time periods during which national regulators may not approve generic drugs on the basis of bioequivalence or otherwise rely on data provided by the originator (Reichman).

\section{Regulatory Exclusivity for Biosimilars}

The growing importance of regulatory exclusivity to the biopharmaceutical industry is apparent from its role in legislation for the regulation of follow-on biologic products (Higgins and Graham 2009; Schacht and Thomas 2009). A generation ago, Congress provided for periods of regulatory exclusivity ranging from 4 to $7 \frac{1}{2}$ years in the HatchWaxman Act. Today, the biopharmaceutical industry has persuaded Congress to confer 12 years of regulatory exclusivity before the FDA can (p. 189) approve products that are biosimilar to previously approved biologic products, ${ }^{103}$ a period that may extend beyond the expiration of relevant patents.

The United States in 2010 enacted a new regulatory approval pathway for biologic products that are "biosimilar" to or "interchangeable" with previously licensed biologic products, after a 12-year period of regulatory exclusivity for the reference products. Some critics have argued that the 12-year period of exclusivity is excessive (Engelberg et al. 2009; FTC 2009b). Others contend that it is necessary to compensate for deficiencies in patents (Higgins and Graham 2009) and have argued for even longer periods (Grabowski 2008). This section sets aside the complex empirical question of the proper duration of exclusivity and focuses on the structure of the statutory regime, evaluating its provisions in light of the analysis of prior regulatory exclusivity regimes set forth previously. 


\section{Disentangling Regulatory Exclusivity From Patent Protection}

A significant improvement over the Hatch-Waxman regime in the biosimilars legislation is that it goes far toward disentangling regulatory exclusivity from patent protection. Whereas under the Hatch-Waxman Act the dates when an ANDA may be filed or approved turn in part on the expiration dates of patents listed in the Orange Book for the listed product and on the status of litigation between the parties regarding those patents, these dates are fixed for biosimilars: irrespective of patents, an application for a biosimilar license may not be filed for four years, and its approval may not be made effective for 12 years, after the first licensing of the reference product. ${ }^{104}$ The FDA is not charged with maintaining an archive of relevant patents in the Orange Book. Instead, a complex set of provisions direct the parties to exchange confidential information relevant to potential patent infringement litigation directly with each other and to negotiate over the scope of such litigation. ${ }^{105}$ The FDA receives notice and a copy of the complaint in any patent infringement action and publishes such notice in the Federal Register, ${ }^{106}$ but there is no provision for the FDA to enter a stay of regulatory approval of the biosimilar license pending resolution of the litigation. Instead, the biosimilar applicant must give notice to the reference product sponsor 180 days before first commercial marketing of its product, allowing the reference product sponsor to seek relief from the court in an infringement action. ${ }^{107}$

(p. 190) This approach has a number of advantages over the Hatch-Waxman regime. It does not put the FDA in the role of patent enforcer but leaves this task to the courts. Innovators thus have no incentive to list dubious patents in the Orange Book to obtain a 30-month stay of regulatory approval from an agency that is unwilling to evaluate patent claims. Remedies for infringement follow adjudication in the courts rather than arising automatically at the outset based on the patent holder's allegations. The timing and duration of regulatory exclusivity are certain and do not depend on the vicissitudes of either infringement litigation or regulatory lag times (unless regulatory approval takes longer than the eight years between the date when an application may be filed and the date when its license may become effective).

\section{Supplemental Exclusivity}

In contrast to the Hatch-Waxman Act, which affords three years of supplemental exclusivity after FDA approval of a supplement to an NDA that required further clinical trials, the biosimilars legislation does not offer additional periods of exclusivity for minor product changes requiring further clinical trials to obtain supplemental approval. An important exception is made for "a modification to the structure of the biological product" that results "in a change in safety, purity, or potency." 108 Such a modification gets its own full 12-year period of regulatory exclusivity. Moreover, the legislation adds six months of "pediatric exclusivity" both to the four-year period before an application for a biosimilar 


\section{Patents and Regulatory Exclusivity}

license may be filed and to the 12-year period before the license may become effective, under the same conditions applicable to pediatric exclusivity for drugs. ${ }^{109}$

The different approach to supplemental exclusivity in biosimilars legislation may reflect the limited value that biopharmaceutical innovators have found in the supplemental exclusivity conferred under the Hatch-Waxman Act. ${ }^{110}$ Although that Act nominally awards three years of additional exclusivity for supplemental approvals for changes such as new indications, the terms of exclusivity are limited to the terms of the supplemental approval, allowing approval of competing products for the old indications. If supplemental exclusivity does not defer FDA approval of the same product for other indications, the generic product will inevitably be substituted when the reference product is prescribed for the new indication. Perhaps there are no comparable rights in the new legislation because nobody bothered to ask for them.

On the other hand, if the supplemental approval is for a structural change to the product that changes its safety, purity, or potency, generic substitution is unlikely, and additional exclusivity is likely to be valuable. In these circumstances, (p.191) the new legislation not only provides exclusivity but expands it to the full 12-year term given for new products.

This approach may both overreward structural changes and undermotivate other changes that require investments in clinical trials. A better approach might be to emulate the European system by conferring an additional period of exclusivity for conducting trials of new indications of a product after initial market approval. Such trials provide better information to guide the use of existing products, rather than distorting innovation incentives in favor of structural changes. Regrettably, the US biosimilars legislation does nothing to promote this valuable form of incremental innovation.

\section{Limits of Abbreviation in Approval Pathway for Biosimilars}

The biosimilars legislation does less to lower the regulatory entry barrier to follow-on competition for biologics than the Hatch-Waxman Act did for generic versions of smallmolecule drugs. Although an applicant need not make the showing required for an ANDA that the active ingredient is "the same" as that of the listed drug, it must demonstrate that its product is "biosimilar to a reference product" based on data derived from analytical studies, animal studies, and one or more clinical studies "that are sufficient to demonstrate safety, purity, and potency" in a use for which the reference product is licensed, unless the FDA determines that one of these elements is unnecessary. ${ }^{111}$

Although a showing of "biosimilarity" is sufficient to obtain a biologics license for the follow-on product, a more extensive showing is necessary to get an agency determination that the biosimilar product is "interchangeable" with the reference product. ${ }^{112} \mathrm{~A}$ determination of interchangeability requires information showing that the biosimilar product "can be expected to produce the same clinical result as the reference product in any given patient" and, for products administered more than once, that "the risk in terms 
of safety or diminished efficacy of alternating or switching between use of the biologic product and the reference product is not greater than the risk of using the reference product without such alternation or switch."113

Without a determination of interchangeability, investments in marketing may be necessary to get physicians and pharmacists to switch their patients from the reference product to the biosimilar product. Moreover, products that are merely "biosimilar" but not "interchangeable" might not trigger generic substitution by pharmacists under state laws (Grabowski and Vernon 1979). By contrast, a determi (p. 192) nation of "bioequivalence" for a generic drug under an ANDA is enough to permit or even compel pharmacists to substitute the less expensive generic version unless the physician directs otherwise (Engelberg et al. 2009). Because most biologics are infusions that are dispensed by physicians in their offices, rather than by pharmacists, substitution of biosimilars will depend more on incentives and decisions of physicians than on those of pharmacists.

It is unclear at this point how much it will cost to show biosimilarity and interchangeability to the satisfaction of the FDA, but informed observers expect that the costs will be considerably higher than what is incurred to show bioequivalence in an ANDA. An FTC report estimates that it will take 8 to 10 years to develop a follow-on biologic, at a cost between $\$ 100$ million and $\$ 200$ million, compared with three to five years at a cost of $\$ 1$ million to $\$ 5$ million to develop a generic small-molecule drug (FTC 2009b). PhRMA estimated the cost of developing a biosimilar at a more modest $\$ 10$ to $\$ 40$ million (Wheadon 2010). Either way, it is clear that the regulatory entry barrier for follow-on biologics will remain much higher than that facing manufacturers of generic drugs. Moreover, further marketing costs may be necessary to persuade physicians, pharmacists, and payers to switch to these products. This may in part be an inevitable consequence of differences between drugs and biologics, but it is also now in part a function of deliberate legislative policy.

\section{Exclusivity for Follow-on Products}

The first follow-on product to receive a determination of interchangeability is entitled to a period of exclusivity before the FDA will make a determination of interchangeability for a competing product. ${ }^{114}$ A biosimilarity determination is not enough to trigger exclusivity for the follow-on product, and exclusivity for the first product determined to be interchangeable with a reference product does not preclude licensure of a competing product that is determined to be merely biosimilar to the reference product but not interchangeable with it. Follow-on exclusivity ends at the earlier of one year after first commercial marketing, ${ }^{115} 18$ months after a final court decision in a patent infringement action against the applicant or dismissal of such an action, ${ }^{116} 42$ months after approval if the applicant has been sued and the litigation is still ongoing, ${ }^{117}$ or 18 months after approval if the applicant has not been sued. ${ }^{118}$ 
This provision corrects some of the design flaws that have come to light in the provision for generic exclusivity in the Hatch-Waxman Act (some of which were (p. 193) fixed in subsequent amendments). Rather than encouraging litigation by rewarding the first applicant to challenge a patent, the proposal rewards the first applicant to receive a determination of interchangeability. This encourages applicants to make the more difficult showing of interchangeability in addition to biosimilarity, and it encourages alacrity in securing a license from the FDA rather than promising rights on the basis of application filing dates. Moreover, the proposal limits the duration of exclusivity in ways that may not be avoided by delays in marketing, litigation, or settlement agreements.

On the other hand, it remains to be seen whether the exclusivity for follow-on biologics will prove as valuable as Hatch-Waxman generic exclusivity. Although the periods of exclusivity appear longer under the biologics legislation than the 180 days provided under the Hatch-Waxman Act, other follow-on products may obtain licenses during the exclusivity period based on a showing of biosimilarity to the reference product, potentially eroding sales and profits for the first interchangeable product. As a result, incentives to introduce follow-on biologics may be limited.

\section{Why Regulatory Exclusivity Rather than Patents?}

One might ask whether it makes sense to provide protection against competition in pharmaceutical markets through regulatory exclusivity rather than through patent law (Thomas 2010). Economic incentives for R\&D are traditionally the province of the patent system and arguably outside the core competence of drug regulators in protecting health. If patents are failing to provide the exclusivity necessary to promote pharmaceutical $R \& D$, might it make more sense to fix the patent system than to fortify regulatory exclusivity?

It is not easy to fix the patent system to meet the particular needs of any one industry. The patent system is a one-size-fits-all legal regime that applies essentially the same rules to inventions arising in biopharmaceutical research, automotive engineering, information technology, semiconductors, rocket science, and even business methods, although the needs of these fields for patent protection differ greatly (Cohen et al. 2000). It is difficult to fine-tune the patent laws to meet the needs of the pharmaceutical industry without upsetting the balance of protection and competition in other industries. ${ }^{119} \mathrm{US}$ patent law has some industry-specific provisions, including the Hatch-Waxman patent term extension pro (p. 194) visions. ${ }^{120}$ But there are limits to how far these provisions can go before they put the United States in violation of the TRIPS Agreement, which requires signatories to provide patent protection "without discrimination as to the place of invention, the field of technology and whether products are imported or locally produced"121 (Dinwoodie and Dreyfuss 2007). The patent law doctrines that have proved problematic for the 


\section{Patents and Regulatory Exclusivity}

pharmaceutical industry, such as the novelty and nonobviousness requirements, are not minor details but bedrock principles. The pharmaceutical industry favored the prohibition in the TRIPS Agreement against discrimination as to field of technology because it would require member states to eliminate national laws that weakened drug patents (such as compulsory licensing provisions) (Weissman 1996). But the treaty language seems to prohibit discrimination in favor of drug patents as well as against them. Regulatory exclusivity may offer a way around these legal and political problems.

Enhanced regulatory exclusivity offers other advantages over stronger patent protection. First, drug regulators enforce regulatory exclusivity without the need for owners to bring costly and risky infringement actions. This may be particularly advantageous in countries that do not have well-functioning institutions for patent enforcement, but even in the United States the costs and risks of infringement litigation are considerable. Second, regulatory exclusivity may rest on more solid legal ground than patent protection. The risks of invalidity are considerable for many drug patents, especially for follow-on patents that face considerable prior art. Third, apart from its more limited duration, regulatory exclusivity is a better temporal fit with the life cycle of a pharmaceutical product. Regulatory exclusivity periods typically do not begin until a product is on the market, whereas much or all of a patent term may run before that time. Finally, the scope of regulatory exclusivity generally corresponds better to relevant product markets than do patents. Regulatory exclusivity tracks the terms of regulatory product approvals, whereas patent claims, drafted to distinguish an invention from the prior art, may correspond less closely to any actual commercial product.

From a political economy perspective, it may be easier for interest groups to influence policy initiatives that focus narrowly on a particular industry (e.g., modifications in drug regulation) than to influence policy initiatives that have a broader impact (e.g., modifications in patent law), because the broader the implications of the policy, the more likely they are to encounter competition from other interest groups. The pharmaceutical industry has sometimes found itself in opposition to the financial services and information technology industries, for example, in legislative debates about patent law reform (Kahin 2007). On the other hand, the biopharmaceutical industry was quite successful in shaping the terms of recent biosimilars legislation to secure generous benefits for its members (Greenwood 2010). Perhaps an industry-specific approach increases the risk that policy makers will be (p. 195) unduly influenced by industry rent-seeking to the detriment of other interests that are less vigorously represented in policy debates (Landes and Posner 2004).

On the other hand, the laws conferring regulatory exclusivity might prove to be less durable than the patent laws. It is politically and legally difficult to change the patent system, particularly in the post-TRIPS era, but there are many levers to push in the drug regulation system to either enhance or chip away at the regulatory exclusivity that supports drug prices. If legislatures and regulators have more latitude to change the rules governing regulatory exclusivity, those rules may be more vulnerable to shifting 
political currents, leading to loss of protection when the public is more concerned with controlling the costs of drugs and to increased protection when industry has greater political influence.

\section{Conclusion}

The current overlapping legal protections for exclusivity in the pharmaceutical marketplace reflect a series of political compromises, repeatedly renegotiated to correct for unintended consequences in the previous version of the rules. Patents and patent challenges play a central role in this system of protection, and many of the patents at stake are ultimately held invalid in litigation. It is not easy to untangle a complex legal regime that allocates billions of dollars of profits. But it makes little sense for lawmakers and trade negotiators to extend this Byzantine system into new legal regimes, either by duplicating the Hatch-Waxman Act for biosimilars or by binding US trading partners to adopt similar systems in their national laws. A simpler and more effective legal regime would rely less on patent protection and more on well-designed regulatory exclusivity to support incentives for new drug development. Recent biosimilars legislation in the United States, although controversial in specifics, corrects some problematic structural features of the Hatch-Waxman Act, disentangling regulatory exclusivity from patents and offering greater incentives to develop products that may be inadequately protected by a patent system that is often asynchronous with biopharmaceutical product development.

\section{References}

Agranat, I., and S.R. Wainschtein. 2010. "The Strategy of Enantiomer Patents of Drugs." Drug Discovery Today 15:163-170.

Bessen, J., and Meurer, M.J. 2008. Patent Failure: How Judges, Bureaucrats \& Lawyers Put Innovators at Risk. Princeton, NJ: Princeton University Press.

Burk, D.L., and M.A. Lemley. 2009. The Patent Crisis and How the Courts Can Solve It. Chicago: University of Chicago Press.

(p. 196) Cohen, W.M., R.R. Nelson, and J.P. Walsh. 2000. Protecting Their Intellectual Assets: Appropriability Conditions and Why U.S. Manufacturing Firms Patent (Or Not). NBER Working Paper 7552. Cambridge, MA: National Bureau of Economic Research.

Congressional Budget Office. 1998. How Increased Competition from Generic Drugs Has Affected Prices in the Pharmaceutical Industry. CBO Report. Washington, DC: CBO.

Crane, D.A. 2002. "Exit Payments in Settlement of Patent Infringement Lawsuits: Antitrust Rules and Economic Applications." Florida Law Review 54: 747-798. 
Crane, D.A. 2004. "Ease Over Accuracy in Assessing Patent Settlements." Minnesota Law Review 88: 698-711.

Curtiss, F.R. 2008. “Perspectives on the 'Generic Cliff': Pushing and Falling.” Journal of Managed Care Pharmacy 14: 318-321.

Dinh, T.Q. 2007. "Potential Pathways for Abbreviated Approval of Generic Biologics Under Existing Law and Proposed Reforms in the Law." Food and Drug Law Journal 62: 77-137.

Dinwoodie, G.B., and R.C. Dreyfuss. 2007. "Diversifying Without Discriminating:

Complying with the Mandates of the TRIPS Agreement." Michigan Telecommunications and Technology Law Review 13: 445-456.

Eisenberg, R.S. 2007. "The Role of the FDA in Innovation Policy." Michigan Telecommunications and Technology Law Review 13: 345-388.

Eisenberg, R.S. 2008. “Pharma's Nononobvious Problem.” Lewis and Clark Law Review 12: 375-430.

Engelberg, A.B. 1999. "Special Patent Provisions for Pharmaceuticals: Have They Outlived Their Usefulness? A Political, Legislative and Legal History of U.S. Law and Observations for the Future." IDEA: Journal of Law and Technology 39(3): 389-428.

Engelberg, A.B., A.S. Kesselheim, and J. Avorn. 2009. “Balancing Innovation, Access and Profits: Market Exclusivity for Biologics.” New England Journal of Medicine 361: 19171919.

Federal Trade Commission. 2002. Generic Entry Prior to Patent Expiration: An FTC Study. Washington, DC: FTC.

Federal Trade Commission. 2009a. Authorized Generics: An Interim Report. Available at http://www.ftc.gov/os/2009/06/P062105authorizedgenericsreport.pdf (accessed November 2011).

Federal Trade Commission. 2009b. Emerging Health Care Issues: Follow-on Biologic Drug Competition. Available at http://www.biosimilars.com/

FTC_FOBS_biosimilars_report.pdf (accessed November 2011).

Federal Trade Commission. 2010. Pay-for-Delay: How Drug Company Pay-Offs Cost Consumers Billions. Washington, DC: FTC. Available at http://www.ftc.gov/os/

2010/01/100112payfordelayrpt.pdf (accessed November 2011).

Fellmeth, A.X. 2004. "Secrecy, Monopoly, and Access to Pharmaceuticals in International Trade Law: Protection of Marketing Approval Data Under the TRIPs Agreement." Harvard International Law Journal 45: 443-502. 


\section{Patents and Regulatory Exclusivity}

Final Act Embodying the Results of the Uruguay Round of Multilateral Trade Negotiations, Annex 1C: Agreement on Trade-Related Aspects of Intellectual Property Rights, 33 I.L.M. 1197 (TRIPS Agreement). 1994. Available at http://www.wto.org/ english/docs_e/legal_e/27-trips.pdf (accessed November 2011).

Food and Drug Administration. 2003a. FDA Center for Drug Evaluation: Guidance for Industry 180-Day Exclusivity When Multiple ANDAs Are Submitted on the Same Day. Washington, DC: FDA.

(p. 197) Food and Drug Administration. 2003b. Applications for FDA Approval to Market a New Drug: Patent Submission and Listing Requirements and Application of 30-Month Stays on Approval of Abbreviated New Drug Applications Certifying That a Patent Claiming a Drug Is Invalid or Will Not Be Infringed; Final Rule, 68 Fed. Reg. 36675 (June 18, 2003).

Food and Drug Administration. 2006. From Test Tube to Patient: Protecting America's Health Through Human Drugs, 4th ed. FDA 06-1524G. Available at http://www.fda.gov/ downloads/Drugs/DevelopmentApprovalProcess/ HowDrugsareDevelopedandApproved/ApprovalApplications/ AbbreviatedNewDrugApplicationANDAGenerics/UCM154807.pdf (accessed December 2011).

Food and Drug Administration. 2007. 2007 Center for Drug Evaluation and Research Update. Available at http://www.fda.gov/downloads/AboutFDA/CentersOffices/CDER/ WhatWeDo/UCM121704.pdf (accessed November 2011).

Furrow, M.E. 2008. "Pharmaceutical Patent Life-Cycle Management after KSR v Teleflex." Food and Drug Law Journal 63: 275-320.

Grabowski, H.G. 2008. "Follow-on Biologics: Data Exclusivity and the Balance Between Innovation and Competition." Nature Reviews Drug Discovery 7: 479-488.

Grabowski, H.G., and M. Kyle. 2007. "Generic Competition and Market Exclusivity Periods in Pharmaceuticals." Managerial and Decision Economics 28: 491-502.

Grabowski, H.G., and J.M. Vernon. 1979. "Substitution Laws and Innovation in the Pharmaceutical Industry.” Law and Contemporary Problems 43: 43-66.

Greenwood, J. 2010. "State of the Industry Address from 2010 BIO International Convention." Available at http://biotech-now.org/2010/05/10/state-industry-addressfrom-2010-bio-international-convention (accessed November 2011).

Hemphill, C.S. 2009. "An Aggregate Approach to Antitrust: Using New Data and Rulemaking to Preserve Drug Competition." Columbia Law Review 109: 629-688.

Higgins, M.J., and S.J.H. Graham. 2009. "Balancing Innovation and Access: Patent Challenges Tip the Scales.” Science 326: 370-371. 
Hovenkamp, H. 2004. "Sensible Antitrust Rules for Pharmaceutical Competition." University of San Francisco Law Review 39: 11-32.

Hovenkamp, H., M. Janis, and M.A. Lemley. 2003. "Anticompetitive Settlement of Intellectual Property Disputes.” Minnesota Law Review 87: 1719-1766.

Hovenkamp, H., M.D. Janis, and M.A. Lemley. 2004. "Balancing Ease and Accuracy in Assessing Pharmaceutical Exclusion Payments." Minnesota Law Review 88: 712-722.

Junod, V. 2004. “Drug Marketing Exclusivity Under United States and European Union Law." Food and Drug Law Journal 59: 479-518.

Kahin, B. 2007. "Patents and Diversity in Innovation." Michigan Telecommunications and Technology Law Review 13: 389-399.

Landes, W.M., and R.A. Posner. 2004. "The Political Economy of Intellectual Property Law." Washington DC: AEI-Brookings Joint Center for Regulatory Studies. Available at http://www.aei.org/docLib/20040608_Landes.pdf (accessed November 2011).

Leffler, K., and C. Leffler. 2004. "Efficiency Trade-Offs in Patent Litigation Settlements: Analysis Gone Astray?” University of San Francisco Law Review 39: 33-54.

Lou, K., and M. deRond. 2006. “The 'Not Invented Here' Myth.” Nature Reviews Drug Discovery 5: 451-452.

Levin, R.C., A.K. Klevorick, R.R. Nelson, and S.G. Winter. 1987. "Appropriating the Returns from Industrial Research and Development." Brookings Papers on Economic Activity 3: 783-820.

(p. 198) Mahecha, L.A. 2006. "Rx-to-OTC Switches: Trends and Factors Underlying Success." Nature Reviews Drug Discovery 5: 380-386. Available at http:// www.nature.com/nrd/journal/v5/n5/pdf/nrd2028.pdf (accessed November 2011).

Mayhew, S. 2010. "Trends in Discovery Externalization." Nature Reviews Drug Discovery 9: 183.

Mossinghoff, G.J. 1999. "Overview of the Hatch-Waxman Act and its Impact on the Drug Development Process." Food and Drug Law Journal 54: 187-194.

O’Rourke, M.A., and J.F. Brodley. 2003. “An Incentives Approach to Patent Settlements: A Commentary on Hovenkamp, Janis and Lemley." Minnesota Law Review 87: 1767-1788.

Perri, A.J. III, and S. Hsu. 2003. "A Review of Thalidomide's History and Current Dermatological Applications.” Dermatology Online Journal 9: 5. Available at http:// dermatology.cdlib.org/93/reviews/thalidomide/hsu.html (accessed November 2011). 
Pharmaceutical Research and Manufacturers of America. 2007. Drug Discovery and Development , Understanding the $R \& D$ Process. Available at http://www.phrma.org/ sites/default/files/159/rd_brochure_022307.pdf (accessed December 2011Pulsinelli, G.A. 1999. "The Orphan Drug Act: What's Right With It.” Santa Clara Computer and High Technology Law Journal 15: 299-346.

Reichman, J.H. 2009. "Rethinking the Role of Clinical Trial Data in International Intellectual Property Law: The Case for a Public Goods Approach." Marquette Intellectual Property Law Review 13: 1-68.

Roin, B. 2009. “Unpatentable Drugs and the Standards of Patentability.” Texas Law Review 87: 503-570

Schacht, W.H., and J.R. Thomas. 2009. Follow-On Biologics: Intellectual Property and Innovation Issues. Washington, DC: Congressional Research Service. Available at http:// www.ipmall.info/hosted_resources/Crs/RL33901_090320.pdf (accessed November 2011).

Schildkraut, M.G. 2004. "Patent-Splitting Settlements and the Reverse Payment Fallacy" Antitrust Law Journal 71: 1033-1068.

Steinbrook, R. 2002. "Testing Medications in Children." New England Journal of Medicine 347: 1462-1470.

Thomas, J.R. 2006. Authorized Generic Pharmaceuticals: Effects on Innovation. Washington, DC: Congressional Research Service. Available at http:// www.orangebookblog.com/files/thomas_j.,\%20Authorized\%20Generics.pdf (accessed November 2011).

Thomas, J.R. 2010. “Toward a Theory of Marketing Exclusivities.” Working paper on file with the author.

Weissman, R. 1996. “A Long, Strange TRIPS: The Pharmaceutical Industry Drive to Harmonize Global Intellectual Property Rules, and the Remaining WTO Legal Alternatives Available to Third World Countries." University of Pennsylvania Journal of International Economic Law 17: 1069-1126.

Wheadon, D.E. 2010 (February 18). "Letter to the Editor." New England Journal of Medicine 362: 661-662.

\section{Notes:}

(1.) Codified as amended at 21 U.S. Code $\S 301$ et seq.

(2.) Pub. L. No. 97-414, 96 Stat. 2049 (1983).

(3.) Pub. L. No. 98-417, 98 Stat. 1585 (1984). 
(4.) Codified as amended at 42 U.S. Code $\S 262$ et seq.

(5.) Some hormone products have been regulated as drugs rather than biologics, allowing for the possible approval of follow-on products under a less used regulatory approval pathway codified at 21 U.S. Code § 505(b)(2) (Dinh 2007).

(6.) The Biologics Price Competition and Innovation Act of 2009, signed into law as Title VII, Subtitle A, §§ 7001-03 of the Patient Protection and Affordable Care Act, Pub. L. No. 111-148 (H.R. 3590) (2010), permits the use of an abbreviated pathway for a biological product that is "biosimilar" to a previously licensed biological product after a 12-year period following initial approval of the reference product.

(7.) Patents are national in scope, although international treaties have brought about some degree of harmonization in the patent laws of member nations. See, for example, Final Act Embodying the Results of the Uruguay Round of Multilateral Trade Negotiations, Annex 1C: Agreement on Trade-Related Aspects of Intellectual Property Rights, 33 I.L.M. 1197 (1994), available at http://www.wto.org/english/docs_e/legal_e/27trips.pdf (accessed November 2011) (hereinafter TRIPS Agreement).

(8.) 35 U.S. Code $\S 102$.

(9.) 35 U.S. Code §§ 101, 112.

(10.) 35 U.S. Code $\S 103$.

(11.) 35 U.S. Code $\S 112$.

(12.) 35 U.S. Code $\S \S 131,132$.

(13.) A patent may be invalidated by the Patent and Trademark Office following reexamination, 35 U.S. Code $\S$ 301-318, or by a court in an infringement action, 35 U.S. Code $\S \S 281-282$. Under $\S 6$ of the Leahy-Smith America Invents Act, Pub. L. 112-29 (H.R. 1249) (2011) [hereinafter "the America Invents Act"], beginning September 16, 2012, third parties will be able to petition the Patent and Trademark Office to cancel claims of a patent as unpatentable in a post-grant review proceeding within nine months of the date the patent is issued or reissued. 35 U.S. Code $\S 321-329$.

(14.) 35 U.S. Code §§ 102, 103.

(15.) 35 U.S. Code $\S 102(b)$. Under the rules in effect as of this writing, a patent applicant has a one-year grace period within which to file a patent application after the invention is disclosed or made obvious by a patent, printed publication, public use, or sale of the invention. For patent claims with effective filing dates after March 16, 2013, this grace period is only available for disclosures by the inventor, disclosures by someone who obtained the subject matter from the inventor, and disclosures by others after public disclosure by the inventor. 35 U.S. Code $§ 102(b)(1)$. 
(16.) 35 U.S. Code $\S 101$.

(17.) 35 U.S. Code $§ 112$.

(18.) Brenner v. Manson, 383 U.S. 519, 536 (1966) (patent application claiming a method of making a novel steroid did not satisfy the utility standard of showing "specific benefit ... in currently available form" where the steroid produced by the method was useful only as "an object of scientific research").

(19.) In Re: Brana, 51 F.3d 1560 (Fed. Cir. 1995) (reversing rejection for lack of utility of a patent application claiming a compound that showed antitumor activity in vitro).

(20.) See Rasmusson v. Smithkline Beecham, 413 F.3d 1318, 1324-25 (Fed. Cir. 2005)

(21.) Most patent applications are published 18 months after their filing dates. See 35 U.S. Code § 122(b).

(22.) In Re: Papesch, 315 F.2d 381 (C.C.P.A. 1963).

(23.) In Re: Dillon, 919 F.2d 688 (Fed. Cir. 1990).

(24.) Knoll Pharmaceutical Co. v. Teva Pharmaceuticals USA Inc., 367 F.3d 1381 (Fed. Cir. 2004).

(25.) 339 F.3d 1373 (Fed. Cir. 2003).

(26.) Merck v. Teva, 395 F.3d 1364 (Fed. Cir. 2005) (weekly rather than daily administration of biphosphonates).

(27.) Alza v. Mylan, 464 F.3d 1286 (Fed. Cir. 2006) (timed-release formulation of oxybutynin).

(28.) For example, McNeil-PPC, Inc. v. L. Perrigo Co., 337 F.3d 1362 (Fed. Cir. 2003) (combination of antidiarrheal compounds and simethicone to treat accompanying flatulence); Richardson-Vicks v. Upjohn, 122 F.3d 1476, 44 USPQ2d (BNA) 1181 (Fed. Cir. 1997) (combination of ibuprofen and pseudoephedrine). But see Knoll Pharmaceutical Co. v. Teva Pharmaceuticals USA Inc., 70 USPQ2d 1957 (Fed. Cir. 2004) (upholding validity of patent on combination of hydrocodone and ibuprofen based on data from trials after the patent grant showing surprising properties).

(29.) For example, Aventis Pharma Deutschland v. Lupin, 499 F.3d 1293 (Fed. Cir. 2007) (ramipril).

(30.) 35 U.S. Code $\S 271(e)(1)$.

(31.) Merck KGaA v. Integra Lifesciences I, 545 U.S. 193 (2005).

(32.) 35 U.S. Code § 154. 
(33.) Uruguay Round Agreement Act, Pub. L. No. 103-465, 108 Stat. 4809, 4814 (1994).

(34.) See supra note 7.

(35.) 35 U.S. Code § 154 (c)(1).

(36.) A continuation is a patent application that relies on the filing date and disclosure of an older patent application (called a "parent") that has not yet been issued or abandoned. 35 U.S. Code $\S 120$. A continuation may add new claims but may not add new matter to the disclosure without losing the benefit of the earlier filing date. Agilent Technologies v. Affymetrix, 567 F.3d 1366, 1389 (Fed. Cir. 2009). In 2007, the PTO sought to limit the use of multiple continuations by administrative rule. 72 Fed. Reg. 46716 (Aug. 21, 2007), available at http://www.uspto.gov/web/offices/com/sol/notices/72fr46716.pdf (accessed November 2011). A panel of the Court of Appeals for the Federal Circuit upheld the authority of the PTO to implement the rule, Tafas v. Dudas, 559 F.3d 1345 (Fed. Cir. 2009), but this decision was vacated and the appeal reinstated pursuant to a grant of rehearing en banc (i.e., by the full court). 328 Fed. Appx. 658; 2009 U.S. App. LEXIS 14611; 91 U.S.P.Q.2D (BNA) 1153 (Fed. Cir. 2009).

(37.) For example, see Takeda Pharmaceutical v. Doll, 531 F.3d 1372 (Fed. Cir. 2009) (considering challenge to validity of manufacturing process for cephem compounds claiming priority from 1974 filing date).

(38.) Geneva v. GlaxoSmithKline, 349 F.3d 1373 (Fed. Cir. 2003); In Re: Metoprolol Succinate Patent Litigation (Fed. Cir. 2007).

(39.) See PTO, Manual of Patent Examining Procedure § 1.321, 37 C.F.R. § 1.321, available at http://www.uspto.gov/web/offices/pac/mpep/consolidated_rules.pdf (accessed November 2011).

(40.) For example, see Amgen v. Hoffmann-LaRoche, 2009 U.S. App. LEXIS 20409 (Fed. Cir. 2009); Proctor \& Gamble v. Teva Pharmaceuticals, 566 F.3d 989 (Fed. Cir. 2009); Pfizer v Teva Pharmaceuticals, 518 F.3d 1353 (Fed. Cir. 2008).

(41.) 35 U.S. Code § 156.

(42.) 35 U.S. Code §§ 156 (c), (g)(1)(B), (g)(6).

(43.) 35 U.S. Code § 156(c) (2). The relevant dates are determined by the FDA, and on the basis of those dates the PTO extends the term of the patent. Astra v. Lehman, 71 F. 3d 1578 (Fed. Cir. 1995).

(44.) 35 U.S. Code § 156(c)(1).

(45.) Fisons v. Quigg, 876 F.2d 99 (Fed. Cir. 1989).

(46.) 35 U.S. Code $\S 156(a)(1)$. 
(47.) 35 U.S. Code § 156(a).

(48.) For example, see SmithKline Beecham v. Apotex, 403 F.3d 1331 (Fed. Cir. 2005), invalidating the patent on crystalline paroxetine hydrochloride hemihydrate (PHC hemihydrate). PHC was first approved by the FDA in hemihydrous form in 1992, but the prior art included a patent on PHC in anhydrous form from the 1970s.

(49.) Sometimes generic products were approved without new trials on the basis of published literature under a "paper NDA." 45 Fed. Reg. 82060 (Dec. 12, 1980). Questions about the legality and reach of this mechanism were part of the impetus for the HatchWaxman Act (Engelberg 1999). Although the FDCA now provides for approval of paper NDAs at § 505(b)(2), 21 U.S. Code § 355(b)(2), the significance of this approval pathway has until recently been largely eclipsed by ANDAs. The language of the provision is quite broad, however, and the FDA has interpreted it to allow approval of a drug that is similar but not identical to a previously approved product based in part on previous unpublished studies that the applicant neither conducted nor obtained the right to use (Dinh 2007).

(50.) 35 U.S. Code $\S 271$.

(51.) An ANDA does not require full reports of clinical trials to show safety and efficacy so long as the conditions of use, active ingredients, route of administration, and strength are the same as a previously approved "listed product," the ANDA product is "bioequivalent" to the listed product, and the labeling of the two products is the same. 21 U.S. Code $\S$ 355(j)(2).

(52.) 21 U.S. Code § 355(b)(1).

(53.) FDA Center for Drug Evaluation and Research, Approved Products With Therapeutic Equivalence Evaluations (commonly known as the Orange Book), available at http:// www.accessdata.fda.gov/scripts/cder/ob/default.cfm (accessed November 2011).

(54.) 21 U.S. Code § 355(j)(2)(A)(vii). If the patent covers a method of use for which the ANDA applicant does not seek approval, it may instead include a statement to that effect, known as a "section viii statement." 21 U.S. Code § 355(j)(2)(A)(viii).

(55.) 21 U.S. Code §§ 355(j)(2)(A)(vii)(1), (2), (3), (4).

(56.) 21 U.S. Code § 355(j)(5)(B)(i).

(57.) Nonpatent grounds for rejecting an ANDA are set forth at 21 U.S. Code § 355(j)(4) (A)-(K).

(58.) 21 U.S. Code § 355(j)(5)(B)(ii).

(59.) 21 U.S. Code §§ 355(j)(5)(B)(iii), 505(j)(2)(B).

(60.) 21 U.S. Code § 355(j)(5)(B)(iii). 
(61.) 21 U.S. Code § 355(j)(5)(B)(iv).

(62.) Before a court will enter a preliminary injunction, a plaintiff must show (1) a reasonable likelihood of success on the merits; (2) irreparable harm if an injunction is not granted; (3) a balance of hardships tipping in its favor; and (4) favorable impact of the injunction on the public interest. Amazon.com v. Barnesandnoble.com, 239 F.3d 1343 (Fed. Cir. 2001).

(63.) 35 C.F.R. § 314.53(a), (f). The courts have upheld the FDA's position that it has no duty to screen Orange Book submissions. Apotex v. Thompson, 347 F.3d 1335 (Fed. Cir. 2003); Purepac Pharmaceutical Co. v. Thompson, 354 F.3d 877 (D.C. Cir. 2004). In 2003 Congress amended the statute to permit counterclaims seeking to delist improperly listed patents in ANDA infringement litigation. 21 U.S. Code § 355(j)(5)(C)(ii). But a first filer of an ANDA with a paragraph IV certification may object to the delisting of a patent if delisting would deprive the firm of the 180-day period of generic exclusivity. See Ranbaxy Laboratories v. Leav.itt, 469 F.3d 120 (D.C. Cir. 2006).

(64.) Pub. L. No. 108-173 §§ 1101, 1102 (enacted December 8, 2003) (codified as amended at 21 U.S. code $\S \S 355(j)(2)$ and (5)).

(65.) The new statutory language is codified at 21 U.S. Code § 355(j)(5)(B)(iii).

(66.) The earliest permissible filing date for an ANDA with a paragraph IV certification is four years after initial approval of the NDA. 21 U.S. Code § 355(j)(5)(F)(ii). If an infringement action is commenced within one year of such a filing, the 30-month stay is extended if necessary so that it expires 71/2 years after initial approval of the NDA.

(67.) 21 U.S. Code § 355(j)(5)(B)(iv).

(68.) The permissible filing dates for ANDAs are limited not only by patents but also by the periods of regulatory exclusivity discussed later. In the case of a new chemical entity, the earliest date that an ANDA with a paragraph IV certification may be filed is four years after approval of the NDA. 21 U.S. Code § 355(j)(5)(F)(ii).

(69.) 21 U.S. Code §505(j)(5)(C)(i). See Teva Pharmaceuticals USA v Novartis, 482 F.3d 1330 (Fed. Cir. 2007).

(70.) Shortly before passage of the Bayh-Dole Act, the Court of Appeals for the Federal Circuit held that the use of a patented drug in clinical trials was an act of patent infringement. Roche Prods. v. Bolar Pharmaceutical, 733 F.2d 858 (Fed. Cir. 1984). The Hatch-Waxman Act changed this rule to allow clinical trials and bioequivalence studies during the patent term, thereby facilitating generic entry immediately upon patent expiration. 35 U.S. Code § 271(e)(1). See supra notes 30-31 and accompanying text.

(71.) 35 U.S. Code § 271(e)(2), (3). 
(72.) Bayer AG v. Elan, 212 F.3d 1241 (Fed. Cir. 2000) (ANDA that specified product having crystals with specific surface area [SSA] falling outside scope of patent claims did not infringe patent, even though measured SSA for sample "biobatch" of product produced by the ANDA filer's supplier fell within scope of claims).

(73.) Warner-Lambert v. Apotex, 316 F.3d 1348 (Fed. Cir. 2003) (ANDA that sought approval to market generic only for previously approved uses not covered by patent did not infringe patent on additional unapproved uses of product).

(74.) This might occur if the 30-month stay on ANDA approval expires and the challenger opts for "at-risk launch" or if the court holds that the patent is invalid or not infringed by the ANDA product. 21 U.S. Code $3355(j)(5)(B)(i i i)$.

(75.) For example, Bayer AG v. Biovail, 279 F. 3d 1340 (Fed. Cir. 2002) (infringement action against a commercial product still available to patent holder even though ANDA product had been held not to infringe in prior ANDA litigation).

(76.) A generic challenger may decide to launch its product commercially before the litigation is finally resolved on appeal. This so-called "at-risk launch" puts the generic at risk of damages liability if it is held liable as an infringer (Curtiss 2008).

(77.) The Hatch-Waxman Act specified the remedies available for ANDA infringement as deferral of the effective date of approval of the ANDA until after expiration of the patent; injunctive relief against commercial manufacture, use, offer to sell, sale, or importation; and damages only for such commercial acts. 35 U.S. Code § 271(e)(4). Attorney's fees may also be available in exceptional cases. Id.

(78.) Subsequent ANDA filers will not be entitled to the 180 days of generic exclusivity and will therefore be less motivated to incur litigation costs, but other ANDA filers with the same filing date could share generic exclusivity.

(79.) Multiple ANDA filers may share the 180-day period of generic exclusivity if each files a complete application with a paragraph IV certification on the same date and no previously filed ANDA for the same drug included a paragraph IV certification. 21 U.S. Code § 505(j)(5)(B)(iv)(I), (II)(bb). For blockbuster products, such multiple filings are common on the first date that they are allowed, four years after approval of the NDA. (j) (5)(F)(ii). (FDA Center for Drug Evaluation 2003a). Available at http://www.fda.gov/ downloads/Drugs/GuidanceComplianceRegulatoryInformation/Guidances/ucm072851.pdf (accessed November 2011).

(80.) An "authorized generic" is a product that is marketed and priced as a generic but sold under the authority of the holder of the NDA rather than under an ANDA. The courts have sustained the legality of authorized generics. See Teva Pharmaceuticals v. Crawford, 410 F.3d 51, 54 (D.C. Cir. 2005). Authorized generics increase competition during the period of generic exclusivity and thereby reduce prices to consumers, but the long-term 
effects may be more ambiguous if authorized generics undermine incentives to challenge drug patents by filing paragraph IV certifications (FTC, 2009a).

(81.) Specifically, the revised statute allows multiple ANDA filers on the same date to share the 180-day exclusivity, 21 U.S. Code § 505(J)(5)(B)(iv)(I), (II); redefines the trigger that begins the 180-day period to be the first commercial marketing by any of the first ANDA filers, including an "authorized generic," 21 U.S. Code § 505(j)(5)(B)(iv)(I); and provides for forfeiture of the 180-day exclusivity period if an applicant fails to market the drug within specified periods, withdraws the application, amends the certification, fails to obtain tentative approval for the ANDA, or enters into an agreement that is adjudicated to be in violation of the antitrust laws, or if the relevant patents expire. See 21 U.S. Code $\S 505(\mathrm{j})(5)(\mathrm{D})$.

(82.) According to a 2002 FTC report, 73 percent of ANDA infringement cases result in invalidity when resolved by the courts, suggesting that consumers might be better off if these cases were litigated rather than settled (FTC 2002).

(83.) For example, In Re: Ciprofloxacin Hydrochloride Antitrust Litigation, 544 F.3d 1323 (Fed. Cir. 2008) (no antitrust violation), cert denied sub nom. Ark. Carpenters Health \& Welfare Fund v. Bayer AG, 174 L. Ed. 2d 553 (2009); In Re: Tamoxifen Citrate Antitrust Litigation, 466 F.3d 187 (2d Cir. 2006) (no antitrust violation), cert. denied sub nom. Joblove v. Barr Labs, 127 S. Ct. 3001 (2007); Schering-Plough v. FTC, 402 F.2d 1056 (11th Cir. 2005) (no antitrust violation), cert. denied, 548 U.S. 919 (2006). But see In Re: Cardizem CD Antitrust Litigation, 332 F.3d 896 (6th Cir. 2003) (per se antitrust violation), cert. denied sub nom. Andrx Pharm., Inc. v. Kroger Co., 543 U.S. 939, 125 S. Ct. 307 (2004).

(84.) See supra note 81.

(85.) Medicare Prescription Drug, Improvement and Modernization Act of 2003, Title XI, § 1112 et seq. A summary of these provisions is available at http://www.ftc.gov/os/ 2004/01/040106pharmrules.pdf (accessed November 2011).

(86.) Pub. L. No. 97-414, 96 Stat. 2049.

(87.) Under § 527 of the FDCA, if the FDA approves a new drug application for a drug that it has designated for a rare disease or condition, "the Secretary may not approve another application ... for such drug for such disease or condition for a person who is not the holder of such approved application ... until the expiration of seven years from the date of the approval of the approved application ...." 21 U.S. Code § 360cc(a).

(88.) Genentech, Inc. v. Bowen, 676 F. Supp. 301 (D.D.C. 1987); Sigma-Tau Pharms. v. Schwetz, 288 F.3d 141 (4th Cir. 2002). 
(89.) 21 C.F.R. § 316.3(b)(13)(i), (ii). See Berlex v. FDA, 942 F. Supp. 19 (D.D.C. 1996) (upholding approval of competing beta interferon before end of exclusivity period based on clinical superiority).

(90.) Sigma-Tau Pharms. v. Schwetz, 288 F.3d 141 (4th Cir. 2002).

(91.) 21 U.S. Code § 355(j)(5)(F)(ii).

(92.) 21 U.S. Code § 355(j)(5)(F)(iii).

(93.) 21 U.S. Code § 355(j)(5)(F)(ii).

(94.) 21 U.S. Code § 355(j)(5)(F)(iv).

(95.) Upjohn v. Kessler, 938 F. Supp. 439 (W.D. Mich. 1996).

(96.) Bristol-Myers Squibb v. Shalala, 91 F.3d 1493 (D.C. Cir. 1996).

(97.) Pub. L. No. 105-115,111 Stat. 2296. Although this provision was originally set to expire after five years, Congress has extended it twice. See Best Pharmaceuticals for Children Act of 2002, P.L. 107-109, 115 Stat. 1408 (codified as amended in scattered provisions of Titles 21 and 42 of U.S. Code); Best Pharmaceuticals for Children Act of 2007, Title V of Food and Drug Administration Amendments Act of 2007, P.L. 110-85, 121 Stat. 823, 876 (codified at 21 U.S. Code § 355a).

(98.) See 21 U.S. Code § 355a.

(99.) FDCA § 505A(n), 21 U.S. Code § 355a(n).

(100.) Council Directive 87/21/EEC of 22 December 1986, amending Directive 65/65/EEC on the Approximation of Provisions Laid Down by Law, Regulation, or Administrative Action Relating to Proprietary Medicinal Products. Available at http://ikev.org/docs/eu/ 387L0021.htm (accessed December 22, 2011).

(101.) Council Directive 2004/27/EC of 31 March 2004 amending Directive 2001/83/EC on the Community code relating to medicinal products for human use. Available at http:// eur-lex.europa.eu/LexUriServ/LexUriServ.do?uri=OJ:L:2004:136:0034:0057:EN:PDF (accessed November 2011).

(102.) TRIPS Agreement, supra note 7, Article 39.3.

(103.) See supra note 6.

(104.) Patient Protection and Affordable Care Act, supra note 6, § 7002 (a)(2), to be codified in pertinent part at 42 U.S. Code 262(k)(7)(A) and (B).

(105.) Id. § 7002(a)(2)., to be codified at 42 U.S. Code $\S 262(1)$.

(106.) Id., to be codified at 42 U.S. Code $\S 262(\mathrm{l})(6)(\mathrm{C})$. 
(107.) Id., to be codified at 42 U.S. Code § 262(l)(8).

(108.) Id., to be codified at 42 U.S. Code § 262(k)(7)(C)(ii)(I),(II).

(109.) Id. § 7002(g)(1), to be codified at 42 U.S. Code $\S 262(\mathrm{~m})$.

(110.) See supra note 96 and accompanying text.

(111.) Patient Protection and Affordable Care Act, supra note 6, § 7002 (a)(2), to be codified at 42 U.S. Code $\S 262(\mathrm{k})(2)(\mathrm{A})(\mathrm{i})$, (ii).

(112.) Id., to be codified at 42 U.S. Code § 262(k)(2)(B), (k)(4).

(113.) Id., to be codified at 42 U.S. Code $\S 262(\mathrm{k})(4)$.

(114.) Id., to be codified at 42 U.S. Code § 262(k)(6).

(115.) Id., to be codified at 42 U.S. Code $\S 262(\mathrm{k})(6)(\mathrm{A})$.

(116.) Id., to be codified at 42 U.S. Code $\S 262(\mathrm{k})(6)(B)$.

(117.) Id., to be codified at 42 U.S. Code § 262(k)(6)(C)(i).

(118.) Id., to be codified at 42 U.S. Code $\S 262(\mathrm{k})(6)(\mathrm{C})(\mathrm{ii})$.

(119.) But see Burk and Lemley, 2009 (arguing that courts can apply patent law differently in different industries according to their particular needs).

(120.) 35 U.S. Code § 156.

(121.) TRIPS Agreement, supra note7, at art. 27 (emphasis added). 


\section{Rebecca S. Eisenberg}

Rebecca S. Eisenberg is Robert and Barbara Luciano Professor of Law at the University of Michigan Law School. Professor Eisenberg is a graduate of Stanford University and Boalt Hall School of Law at the University of California, Berkeley, where she was articles editor of the California Law Review. Following law school, she served as law clerk for Chief Judge Robert F. Peckham on the US District Court for the Northern District of California and then practiced law as a litigator in San Francisco. She joined the Michigan Law faculty in 1984. Professor Eisenberg regularly teaches courses in patent law, trademark law, and Food and Drug Administration law, and she runs workshops on intellectual property and student scholarship. She has previously taught courses on torts, legal regulation of science, and legal issues in biopharmaceutical research. She has written and lectured extensively about the role of intellectual property in biopharmaceutical research, publishing in scientific journals as well as law reviews. She spent the 1999-2000 academic year as a visiting professor of law, science, and technology at Stanford Law School. She has received grants from the Ethical, Legal, and Social Implications Program of the Human Genome Project from the US Department of Energy Office of Biological and Environmental Research for her work on private appropriation and public dissemination of DNA sequence information. Professor Eisenberg has played an active role in public policy debates concerning the role of intellectual property in biopharmaceutical research. 